\title{
Effect of Complex Organo-Mineral Modifier on the Properties of Corrosion-Resistant Concrete
}

\author{
Lam Van Tang, ${ }^{1, *}$, Hung Xuan $\mathrm{Ngo}^{1}$, Dien Vu Kim ${ }^{1}$, Boris Bulgakov ${ }^{1}$ and Olga \\ Aleksandrova ${ }^{1}$ \\ ${ }^{1}$ Moscow State University of Civil Engineering, Yaroslavskoe shosse, 26, Moscow, 129337, Russia
}

\begin{abstract}
This paper reports the results of a research study aimed at identifying the compositional features of fly ash (FA) TPP "Pha Lai" (Vietnam), silica fume SF-90 (SF90) and superplasticizer SilkRoad SR $5000 \mathrm{~F}$ (SR5000) contents that influence the sulfate resistance of corrosionresistant concrete. The effect of FA, SF90 and SR5000 on the strength of corrosion-resistant concrete is obtained quickly, high early-strength concrete. In details, the compressive strength at the age of 1 and 3 days are respectively $29.6 \%$ and $61.13 \%$ in comparison to 28 days period. The deformation of corrosion-resistant concrete prisms in 5\% sodium sulfate solution after 28 days of testing were determined by Russian standard GOST P 56687-2015. Using the mathematical planning method for four factors and the Matlab computer programs was obtained the mathematical model, which was adequately described the influence ofthe water-binding ratio, FA, SF90 and SR5000 contents on the concrete deformation. It was also noted that the effect of FA content is more pronounced than the waterbinding ratio and content SF90. In addition, the effect of SR5000 content on the deformation of concrete is negligible, so it was discarded.
\end{abstract}

\section{Introduction}

In the construction world the 21st century will be known as the century of concrete in the oceans. Early cracking of concrete and corrosion are a major concern for all offshore projects. The causes and mitigation alternatives are key aspects of creating and maintaining a sustainable offshore structure and hydroelectric project [1].

Vietnam, located in tropical climate area, has strong differentiation between the rainy season and the dry season. This country stretches lengthen from the North to the South, with a coastline of $3260 \mathrm{~km}$ long. Recently, the number of offshore and hydraulic projects in the coastal marine environment and the delta has increased several times. Based on some research analysis results, more than $50 \%$ of the nodes and structures of the coastal berthing and mooring facilities, breakwaters and tidal barriers, dry docks and jetties, container

\footnotetext{
*Corresponding author: lamvantang@gmail.com
} 
terminals, and offshore floating docks and drilling platforms in Vietnam were completely damaged or destroyed after $5 \div 20$ years operation [2-4].

Accoding to [5-7] the performance of concrete against sulfate attack is associated with the permeability performance and the density of concrete. At the beginning, cement hydration dominantly happened to form a large amount of C-S-H gel, which provided the high strength for concrete mixture at an early ages. After one - two weeks, the pozzolanic reaction significantly happened. In the marine environment, it has happened the ion sulfate attack reaction (Equations 1 - 4) and become more dominant after several weeks. The deformation of gypsum and ettringite formed during the reaction process led to a reduction in strength of the concrete and maybe completely damaged structures.

In sulfate and marine environments, sulfate attack in concrete:

$$
\begin{gathered}
\mathrm{Na}_{2} \mathrm{SO}_{4} \cdot 2 \mathrm{H}_{2} \mathrm{O}+\mathrm{Ca}(\mathrm{OH})_{2} \rightarrow \mathrm{CaSO}_{4} \cdot 2 \mathrm{H}_{2} \mathrm{O}+2 \mathrm{NaOH} \\
\mathrm{Na}_{2} \mathrm{SO}_{4} \cdot 2 \mathrm{H}_{2} \mathrm{O}+\mathrm{C}-\mathrm{S}-\mathrm{H} \rightarrow \mathrm{CaSO}_{4} \cdot 2 \mathrm{H}_{2} \mathrm{O}+\mathrm{N}-\mathrm{S}-\mathrm{H} \\
\mathrm{C}_{4} \mathrm{AH}_{13}+3 \mathrm{CaSO}_{4} \cdot 2 \mathrm{H}_{2} \mathrm{O}+14 \mathrm{H}_{2} \mathrm{O} \rightarrow \mathrm{C}_{3} \mathrm{~A} \cdot 3 \mathrm{CaSO}_{4} \cdot 32 \mathrm{H}_{2} \mathrm{O}+\mathrm{Ca}(\mathrm{OH})_{2} \\
\mathrm{C}_{3} \mathrm{~A} .3 \mathrm{CaSO}_{4} \cdot 12 \mathrm{H}_{2} \mathrm{O}+2 \mathrm{CaSO}_{4} \cdot 2 \mathrm{H}_{2} \mathrm{O}+16 \mathrm{H}_{2} \mathrm{O} \rightarrow \mathrm{C}_{3} \mathrm{~A} \cdot 3 \mathrm{CaSO}_{4} \cdot 32 \mathrm{H}_{2} \mathrm{O}
\end{gathered}
$$

In fact, the deformation depend mainly on the concrete mixture design and to some extent on the type of cement used. In recent years organo-mineral modifiers such as superplasticizer an active mineral additive (natural pozzolan, rice husk ash, bottom ash and fly ash) obtained a wide circulation. The impact of various additives on the high performance concrete quality is studied $[8,9]$. This is associated with the pozzolanic reaction to form the secondary C-S-H gel of mineral additives in concrete mix design $[10,11]$. As such it is important to research effect of the complex organo-mineral modifier on the corrosion resistance of marine structures. In fact, the corrosion resistance of this concrete structures depend mainly on the concrete mixture design and to some extent on the type of cement used.

In this paper, the preliminary composition of corrosion-resistant concrete mixture is calculated according to the standard ACI $211.4 \mathrm{R}-08$. The deformation of corrosion-resistant concrete prisms in $5 \% \mathrm{Na}_{2} \mathrm{SO}_{4}$ solution after 28 days of testing were determined by Russian standard GOST P 56687-2015. The mathematical model is adequately described the influence of the complex organo-mineral modifiers on the concrete deformation.

\section{Experimental work}

\subsection{Materials}

a). Sulphate resisting portland cement (SPC) $\mathrm{PC}_{\mathrm{SR}} 40$, manufactured at "Tam Diep" factory (Vietnam), specific weight of $3.15 \mathrm{~g} / \mathrm{cm}^{3}$. The results of physical properties, mechanical properties and cement's mineralogical composition are presented in Table 1 and 2 respectively.

\begin{tabular}{|c|c|c|c|c|c|c|c|}
\hline \multirow{2}{*}{$\begin{array}{l}\text { Specific weight } \\
\left(\mathrm{g} / \mathrm{cm}^{3}\right)\end{array}$} & \multirow{2}{*}{$\begin{array}{c}\text { Surface } \\
\text { area } \\
\left(\mathrm{cm}^{2} / \mathrm{g}\right)\end{array}$} & \multicolumn{2}{|c|}{ Time of setting ( $\mathrm{min}$ ) } & \multicolumn{3}{|c|}{ Compressive strength (MPa) } & \multirow{2}{*}{$\begin{array}{c}\text { Standard } \\
\text { consistency } \\
(\%)\end{array}$} \\
\hline & & Initial & Final & 3 days & 7 days & 28 days & \\
\hline 3.15 & 3650 & 115 & 245 & 18.4 & 40.5 & 50.2 & 29.5 \\
\hline
\end{tabular}

Table 1. Chemical compositions of sulphate resisting Portland cement $\mathrm{PC}_{\mathrm{SR}} 40$ (\%)

\begin{tabular}{|c|c|c|c|c|c|c|c|}
\hline $\mathrm{CaO}$ & $\mathrm{SiO}_{2}$ & $\mathrm{Al}_{2} \mathrm{O}_{3}$ & $\mathrm{Fe}_{2} \mathrm{O}_{3}$ & $\mathrm{MgO}$ & $\mathrm{R}_{2} \mathrm{O}$ & $\mathrm{SO}_{3}$ & LOI $^{(\mathrm{a})}$ \\
\hline 63.48 & 21.37 & 4.14 & 5.15 & 2.53 & 1.05 & 0.63 & 1.65 \\
\hline Note: & ${ }^{(a)}$ LOI - loss on ignition. \\
L
\end{tabular}

Table 2. Physical and mechanical properties of sulphate resisting Portland cement $\mathrm{PC}_{\mathrm{SR}} 40$

b). Quartz sand (QS): originally from the golden sand of "Lo River" (Vietnam), $\mathrm{M}_{\mathrm{K}}=$ 3.1 , specific weight of $2.65 \mathrm{~g} / \mathrm{cm}^{3}$. The volume of compacted state is $1540 \mathrm{~kg} / \mathrm{m}^{3}$. 
c). Crushed limestone (CL) (Vietnam) with the size of $5 \div 10 \mathrm{~mm}$, specific weight of $2.67 \mathrm{~g} / \mathrm{cm}^{3}$. The volume of the compacted state is $1580 \mathrm{~kg} / \mathrm{m}^{3}$.

d). Fly Ash (FA) TPP "Pha Lai" (Vietnam) class F and Silica Fume SF-90 (SF90) (Vina Pacific). The chemical composition and physical properties of the FA TPP "Pha Lai" and Silica Fume SF-90 are presented in Table 3 and 4.

Table 3. Chemical compositions of FA TPP "Pha Lai" and Silica Fume SF-90

\begin{tabular}{|c|c|c|c|c|c|c|c|c|c|c|}
\hline \multirow{2}{*}{ Mineral additives } & \multicolumn{10}{|c|}{ Average chemical composition (\%) } \\
\cline { 2 - 11 } & $\mathrm{SiO}_{2}$ & $\mathrm{Al}_{2} \mathrm{O}_{3}$ & $\mathrm{Fe}_{2} \mathrm{O}_{3}$ & $\mathrm{SO}_{3}$ & $\mathrm{~K}_{2} \mathrm{O}$ & $\mathrm{Na}_{2} \mathrm{O}$ & $\mathrm{MgO}$ & $\mathrm{CaO}$ & $\mathrm{P}_{2} \mathrm{O}_{5}$ & LOI \\
\hline FA TPP "Pha Lai" & 54.62 & 24.17 & 6.15 & 2.81 & 1.28 & 1.25 & 1.57 & 1.48 & 1.63 & 5.04 \\
\hline Silica Fume SF-90 & 91.65 & 2.25 & 2.47 & - & - & 0.58 & - & 0.51 & - & 2.54 \\
\hline
\end{tabular}

Table 4. Physical properties of FA TPP "Pha Lai" and Silica Fume SF-90

\begin{tabular}{|l|c|c|}
\hline \multicolumn{1}{|c|}{ Свойства } & FA TPP "Pha Lai" & Silica Fume SF-90 \\
\hline Specific weight $\left(\mathrm{g} / \mathrm{cm}^{3}\right)$ & 2.23 & 2.15 \\
\hline The volume of natural porous state $\left(\mathrm{kg} / \mathrm{m}^{3}\right)$ & 770 & 450 \\
\hline Specific surface area $\left(\mathrm{m}^{2} / \mathrm{g}\right)$ & 14.455 & 22.52 \\
\hline Humidity $(\%)$ & 11 & 0 \\
\hline Retained content on sieve with a hole size of $45 \mu \mathrm{m}(\%)$ & 18.6 & 0.25 \\
\hline
\end{tabular}

e). Superplasticizer SilkRoad SR 5000F (SR5000) (South Korea). It is a new generation chemical additives based on polycarboxylate ethers with specific weight of $1.1 \mathrm{~g} / \mathrm{cm}^{3}$ at 20 $\pm 5^{\circ} \mathrm{C}$.

f). Ordinary clean tap water (W) was used for both mixing concrete and curing of test specimens.

\subsection{Methods}

Calculation method of concrete mixture composition is applied in accordance with ACI 211.4R-08 and the volume method. According to ASTM C143, the concrete mixture workability is determined by the standard slump cone with dimensions of $100 \times 200 \times 300 \mathrm{~mm}$.

The compressive strength and tensile strength of corrosion-resistant concrete are by a 100x100x100 mm cube pattern by Russian standard GOST 10180-2012. These test samples are demolded after 24 hours later casting and placed in a $25 \pm 5{ }^{\circ} \mathrm{C}$ water curing tank until the experiments. The corrosion-resistant concrete compressive strengths are measured at the ages of $1,3,7,14$ and 28 days. Deformation of corrosion-resistant concrete exposed to a sulfate solution is determined by a prism pattern of size $25 \times 25 \times 254 \mathrm{~mm}$ by Russian standard GOST P 56687-2015. Furthermore, the mathematical modeling, depicting the dependence of the waterbinding ratio ( $\left.\frac{\mathrm{W}}{\mathrm{BID}}\right)$, FA TPP "Pha Lai", SF90 and SR5000 on the concrete deformation, uses the mathematical experiment planning method with first-order for four factors [12-14].

\section{Results and discussion}

\subsection{Mixture proportions and mixing procedures}

The standard ACI 211.4R-08 (American method), which is used to determine the preliminary composition of the concrete mixture, requires the standard slump cone of $10 \div 18 \mathrm{~cm}$ and allows to obtain $70 \mathrm{MPa}$ compressive strength corrosion-resistant concrete at the age of 28 days with ordinary hardening. In this research used fly ash TPP "Pha Lai" to replace $30 \%$ of 
the mass cement in concrete mixture. The amount of SR 5000F is $1 \%$ by the mass of Portland cement and the decrease of water content of the concrete mixture is about $30 \%$.

All mixtures were mixed in a laboratory "Controls" mixer with a capacity of 150 liters. The mix ingredients placed in the mixer was in the following order; dry aggregates, cement, fly ash and Silica Fume were mixed in the mixer for 5 minutes then chemical additives and water were added gradually in 30 seconds and the mixing continued for 10 minutes. Therefore, the total mixing time was $15 \div 16$ minutes for each concrete mixture. After mixing, a series of 100-mm cubes and prisms of size $25 \times 25 \times 254 \mathrm{~mm}$ concrete specimens were cast in pre-oiled moulds and fully compacted using vibration table and the top surface was leveled and finished by trowel. The fresh concrete properties as well as the concrete properties are represented in Table 5 and 6.

Table 5. Mixture composition and properties of concrete mixture

\begin{tabular}{|c|c|c|c|c|c|c|c|c|c|}
\hline \multicolumn{5}{|c|}{ Concrete mixture compositions $\left(\mathrm{kg} / \mathrm{m}^{3}\right)$} & \multicolumn{3}{|c|}{ Properties of fresh concrete mixture } \\
\hline SPC & FA & SF90 & QS & CL & SR5000 & W & $\frac{\mathrm{W}^{(b)}}{\text { BID }^{\text {Unit weight }}}$ & $\begin{array}{c}\text { Slump } \\
\left(\mathrm{kg} / \mathrm{m}^{3}\right)\end{array}$ & $(\mathrm{cm})$ \\
\hline 406 & 122 & 40.6 & 595 & 1027 & 4.1 & 159 & 0.3 & 2353.7 & 16.5 \\
\hline
\end{tabular}

Note: ${ }^{b} B I D=S P C+F A+S F 90$ and $\frac{\mathrm{W}}{B I D}-$ ratio by weight.

Table 6. Properties of corrosion-resistant concrete

\begin{tabular}{|c|c|c|c|c|c|c|}
\hline \multirow{2}{*}{$\begin{array}{c}\text { Average density of } \\
\text { concrete }\left(\mathrm{kg} / \mathrm{m}^{3}\right)\end{array}$} & \multicolumn{4}{|c|}{ Average compressive strength at different } & \multirow{2}{*}{$\begin{array}{c}\text { Average tensile strength } \\
\text { ages }(\mathrm{MPa})\end{array}$} \\
\cline { 2 - 6 } & 1 days & 3 days & 7 days & 14 days & 28 days & \\
\hline 2326.5 & 21.4 & 44.2 & 55.4 & 66.4 & 72.3 & 6.15 \\
\hline
\end{tabular}

It can be seen from Table 4 that the corrosion-resistant concrete mixture composition calculation with 30\% mass FA, 10\% mass SF90 and 1\% mass SR5000 the specified workability allow to obtain the required strength concrete. In addition, the test results showed that the effect of organic additives on the strength of corrosion-resistant concrete is obtained quickly, high early-strength concrete. In details, the compressive strength at the age of 1 and 3 days are respectively $29.6 \%$ and $61.13 \%$ in comparison to 28 days period.

\subsection{Effect of organic additives on the deformation of corrosion-resistant concrete}

In this paper, the achieved mathematical regression equation of the objective function is the deformation of corrosion-resistant concrete prisms by using the mathematical experiment planning method with first-order for four influencing factors.

\subsubsection{Definition of objective functions for the description of empirical models}

$\mathrm{Y}$ - deformation of corrosion-resistant concrete prisms in $5 \% \mathrm{Na}_{2} \mathrm{SO}_{4}$ solution after 28 days of testing is considered as an objective function of the experimental model and is determined by formula (5):

$$
\begin{aligned}
\mathrm{y} & =\beta_{0}+\beta_{1} \mathrm{x}_{1}+\beta_{2} \mathrm{x}_{2}+\beta_{3} \mathrm{x}_{3}+\beta_{4} \mathrm{x}_{4}+\beta_{5} \mathrm{x}_{1} \mathrm{x}_{2}+\beta_{6} \mathrm{x}_{1} \mathrm{x}_{3}+\beta_{7} \mathrm{x}_{1} \mathrm{x}_{4}+\beta_{8} \mathrm{x}_{2} \mathrm{x}_{3} \\
& +\beta_{9} \mathrm{x}_{2} \mathrm{x}_{4}+\beta_{10} \mathrm{x}_{3} \mathrm{x}_{4}+\beta_{11} \mathrm{x}_{1} \mathrm{x}_{2} \mathrm{x}_{3}+\beta_{12} \mathrm{x}_{1} \mathrm{x}_{3} \mathrm{x}_{4}+\beta_{13} \mathrm{x}_{2} \mathrm{x}_{3} \mathrm{x}_{4}+\beta_{14} \mathrm{x}_{1} \mathrm{x}_{2} \mathrm{x}_{3} \mathrm{x}_{4}
\end{aligned}
$$

where, $\mathrm{Y}$ is the response variable - $(\mathrm{D}, \%)$ deformation of corrosion-resistant concrete prisms after 28 days of testing; $\beta_{0}$ to $\beta_{4}$ are the coefficients of linear model terms; $\beta_{5}$ to $\beta_{10}$ are the coefficients of quadratic model terms, $\beta_{11}$ to $\beta_{14}$ are the coefficients of cubic model terms with added interaction terms; while $\mathrm{x}_{1}, \mathrm{x}_{2}, \mathrm{x}_{3}$ and $\mathrm{x}_{4}$ represent the factors employed during the current optimization studies. 


\subsubsection{Input influencing factors and their limitation}

Input influencing factors and their limitation are sorted as below:

$+\mathrm{x}_{1}$ - the water-binding ratio $\frac{\mathrm{W}}{\mathrm{BID}}$, is in the range from 0.24 to 0.32 ;

$+\mathrm{x}_{2}$ - the content of FA, is in the range from $20 \%$ to $40 \%$ by mass SPC;

$+\mathrm{x}_{3}$ - the content of SF90, is in the range from $5 \%$ to $15 \%$ by mass SPC;

$+\mathrm{x}_{4}$ - the content of SR5000, is in the range from $0.5 \%$ to $1.5 \%$ by mass SPC.

In the concrete mixtures, the QS and CL contents are constants and equal, respectively, $595 \mathrm{~kg}$ and $1027 \mathrm{~kg}$.

The input factors and intervals of their variation are shown in Table 7.

Table 7. Levels and intervals of influencing factors

\begin{tabular}{|c|c|c|c|c|c|}
\hline \multicolumn{2}{|c|}{ Factors } & \multicolumn{3}{c|}{ Levels varying factors } & $\begin{array}{c}\text { Intervals varying } \\
\text { factors }\end{array}$ \\
\hline Parameter & Description & -1 & 0 & +1 & 0.04 \\
\hline$\frac{\mathrm{W}}{\mathrm{BID}}$ & $\mathrm{x}_{1}$ & 0.24 & 0.28 & 0.32 & $10 \%$ \\
\hline The content of FA (\%) & $\mathrm{x}_{2}$ & 20 & 30 & 40 & $5 \%$ \\
\hline The content of SF90 (\%) & $\mathrm{x}_{3}$ & 5 & 10 & 15 & $0.5 \%$ \\
\hline The content of SR5000 (\%) & $\mathrm{x}_{4}$ & 0.5 & 0.1 & 1.5 & \\
\hline
\end{tabular}

The number of necessary experiments - $\mathrm{N}$ in first-order planning was determined by formula (6):

$$
\mathrm{N}=2^{\mathrm{k}} \text {; where } \mathrm{k}-\text { the number of factors, } \mathrm{k}=4 \text {. }
$$

Consequently: $\mathrm{N}=2^{4}=16$.

Compositions of corrosion-resistant concrete, calculated by the method of the mathematical experiment planning for four influencing factors in first-order planning, are displayed in Table 8. The values of deformations concrete in $5 \% \mathrm{Na}_{2} \mathrm{SO}_{4}$ solution after 28 days of testing are presented in Tables 9 .

Table 8. Matrix of first-order planning for four factors and compositions of concrete mixtures

\begin{tabular}{|c|c|c|c|c|c|c|c|c|c|c|c|c|c|c|c|}
\hline \multirow{2}{*}{$\begin{array}{l}\text { Trial } \\
\text { No. }\end{array}$} & \multicolumn{4}{|c|}{ Description of code } & \multicolumn{4}{|c|}{ Parameter } & \multicolumn{7}{|c|}{$\begin{array}{l}\text { Compositions of concrete mixtures } \\
\qquad\left(\mathrm{kg} / \mathrm{m}^{3}\right)\end{array}$} \\
\hline & $\mathrm{x}_{1}$ & $\mathrm{x}_{2}$ & $\mathrm{x}_{3}$ & $\mathrm{x}_{4}$ & $\frac{\mathrm{W}}{\mathrm{BID}}$ & $\begin{array}{c}\mathrm{FA}, \\
\%\end{array}$ & $\begin{array}{c}\text { SF90, } \\
\%\end{array}$ & $\begin{array}{l}\text { SR5000, } \\
\%\end{array}$ & SPC & QS & CL & FA & SF90 & SR5000 & W \\
\hline 1 & + & + & + & + & 0.32 & 40 & 15 & 1.5 & 340 & $\begin{array}{c}59 \\
5\end{array}$ & $\begin{array}{c}102 \\
7\end{array}$ & $\begin{array}{c}13 \\
6\end{array}$ & 51 & 5.1 & 168 \\
\hline 2 & - & + & + & + & 0.24 & 40 & 15 & 1.5 & 384 & $\begin{array}{c}59 \\
5\end{array}$ & $\begin{array}{c}102 \\
7\end{array}$ & $\begin{array}{c}15 \\
4\end{array}$ & 57.6 & 5.8 & 143 \\
\hline 3 & + & - & + & + & 0.32 & 20 & 15 & 1.5 & 396 & $\begin{array}{c}59 \\
5\end{array}$ & $\begin{array}{c}102 \\
7\end{array}$ & 79 & 59.5 & 5.9 & 171 \\
\hline 4 & - & - & + & + & 0.24 & 20 & 15 & 1.5 & 449 & $\begin{array}{c}59 \\
5\end{array}$ & $\begin{array}{c}102 \\
7\end{array}$ & 90 & 67.3 & 6.7 & 145 \\
\hline 5 & + & + & - & + & 0.32 & 40 & 5 & 1.5 & 366 & $\begin{array}{c}59 \\
5\end{array}$ & $\begin{array}{c}102 \\
7\end{array}$ & $\begin{array}{c}14 \\
6\end{array}$ & 18.3 & 5.5 & 170 \\
\hline 6 & - & + & - & + & 0.24 & 40 & 5 & 1.5 & 414 & $\begin{array}{c}59 \\
5 \\
\end{array}$ & $\begin{array}{c}102 \\
7\end{array}$ & $\begin{array}{c}16 \\
5 \\
\end{array}$ & 20.7 & 6.2 & 144 \\
\hline 7 & + & - & - & + & 0.32 & 20 & 5 & 1.5 & 432 & $\begin{array}{c}59 \\
5\end{array}$ & $\begin{array}{c}102 \\
7\end{array}$ & 86 & 21.6 & 6.5 & 173 \\
\hline
\end{tabular}




\begin{tabular}{|c|c|c|c|c|c|c|c|c|c|c|c|c|c|c|c|}
\hline 8 & - & & - & + & 0.24 & 20 & 5 & 1.5 & 490 & $\begin{array}{c}59 \\
5\end{array}$ & $\mid \begin{array}{c}102 \\
7\end{array}$ & 98 & 24.5 & 7.4 & 147 \\
\hline 9 & + & + & + & - & 0.32 & 40 & 15 & 0.5 & 343 & $\begin{array}{c}59 \\
5\end{array}$ & $\begin{array}{c}102 \\
7\end{array}$ & $\begin{array}{c}13 \\
7\end{array}$ & 51.4 & 1.7 & 170 \\
\hline 10 & - & + & + & - & 0.24 & 40 & 15 & 0.5 & 388 & \begin{tabular}{|c|}
59 \\
5
\end{tabular} & $\begin{array}{c}102 \\
7\end{array}$ & $\begin{array}{c}15 \\
5\end{array}$ & 58.1 & 1.9 & 144 \\
\hline 11 & + & - & + & - & 0.32 & 20 & 15 & 0.5 & 400 & $\begin{array}{c}59 \\
5\end{array}$ & $\begin{array}{c}102 \\
7\end{array}$ & 80 & 60.1 & 2 & 173 \\
\hline 12 & - & - & + & - & 0.24 & 20 & 15 & 0.5 & 454 & $\begin{array}{c}59 \\
5\end{array}$ & $\begin{array}{c}102 \\
7\end{array}$ & 91 & 68.1 & 2.3 & 147 \\
\hline 13 & + & + & - & - & 0.32 & 40 & 5 & 0.5 & 369 & $\begin{array}{c}59 \\
5\end{array}$ & $\begin{array}{c}102 \\
7\end{array}$ & $\begin{array}{c}14 \\
8\end{array}$ & 18.4 & 1.8 & 171 \\
\hline 14 & - & + & - & - & 0.24 & 40 & 5 & 0.5 & 418 & $\begin{array}{c}59 \\
5\end{array}$ & $\begin{array}{c}102 \\
7\end{array}$ & $\begin{array}{c}16 \\
7\end{array}$ & 20.9 & 2.1 & 145 \\
\hline 15 & + & - & - & - & 0.32 & 20 & 5 & 0.5 & 437 & \begin{tabular}{|c|}
59 \\
5
\end{tabular} & $\begin{array}{c}102 \\
7\end{array}$ & 87 & 21.8 & 2.2 & 175 \\
\hline 16 & - & - & - & - & 0.24 & 20 & 5 & 0.5 & 496 & $\begin{array}{c}59 \\
5\end{array}$ & $\begin{array}{c}102 \\
7\end{array}$ & 99 & 24.8 & 2.5 & 149 \\
\hline
\end{tabular}

Table 9. Deformations of corrosion-resistant concrete in $5 \% \mathrm{Na}_{2} \mathrm{SO}_{4}$ solution after 28 days of testing

\begin{tabular}{|c|c|c|c|c|c|c|c|c|c|c|c|}
\hline \multirow[b]{2}{*}{$\begin{array}{l}\text { Trial } \\
\text { No. }\end{array}$} & \multicolumn{4}{|c|}{ Parameter } & \multicolumn{6}{|c|}{ Deformations of corrosion-resistant concrete (\%) } & \multirow{2}{*}{$\begin{array}{c}\text { Ошибки } \\
\text { дисперсии } \\
\mathrm{S}_{\mathrm{i}}^{2},\left(10^{-7}\right)\end{array}$} \\
\hline & $\frac{W}{B I D}$ & $\begin{array}{c}\text { FA, } \\
\%\end{array}$ & $\begin{array}{c}\text { SF90 } \\
\%\end{array}$ & $\begin{array}{c}\text { SR5000, } \\
\%\end{array}$ & $D_{1}$ & $\mathrm{D}_{2}$ & $\mathrm{D}_{3}$ & $\mathrm{Y}_{\mathrm{i}}^{\mathrm{cp}}=\mathrm{D}_{\mathrm{i}}^{\mathrm{cp}}$ & $\overline{\mathrm{Y}}_{\mathrm{j}}$ & $\begin{array}{c}\left(\mathrm{Y}_{\mathrm{j}}-\overline{\mathrm{Y}}_{\mathrm{j}}\right)^{2} \\
\left(10^{-5}\right)\end{array}$ & \\
\hline 1 & 0.32 & 40 & 15 & 1.5 & 0.02 & 0.021 & 0.02 & 0.02 & 0.027 & 4.976 & 3.33 \\
\hline 2 & 0.24 & 40 & 15 & 1.5 & 0.034 & 0.035 & 0.035 & 0.035 & 0.035 & 0.006 & 3.43 \\
\hline 3 & 0.32 & 20 & 15 & 1.5 & 0.01 & 0.011 & 0.012 & 0.011 & 0.008 & 0.789 & 3.73 \\
\hline 4 & 0.24 & 20 & 15 & 1.5 & 0.014 & 0.015 & 0.014 & 0.014 & 0.016 & 0.366 & 0.93 \\
\hline 5 & 0.32 & 40 & 5 & 1.5 & 0.032 & 0.034 & 0.033 & 0.033 & 0.033 & 0.071 & 10 \\
\hline 6 & 0.24 & 40 & 5 & 1.5 & 0.043 & 0.044 & 0.042 & 0.043 & 0.041 & 0.197 & 6.03 \\
\hline 7 & 0.32 & 20 & 5 & 1.5 & 0.013 & 0.013 & 0.014 & 0.013 & 0.015 & 0.181 & 0.23 \\
\hline 8 & 0.24 & 20 & 5 & 1.5 & 0.015 & 0.016 & 0.016 & 0.015 & 0.023 & 5.476 & 0.43 \\
\hline 9 & 0.32 & 40 & 15 & 0.5 & 0.029 & 0.03 & 0.03 & 0.029 & 0.027 & 0.648 & 7.43 \\
\hline 10 & 0.24 & 40 & 15 & 0.5 & 0.035 & 0.036 & 0.036 & 0.036 & 0.035 & 48 & \\
\hline 11 & 0.32 & 20 & 15 & 0.5 & 0.013 & 0.013 & 0.013 & 0.013 & 0.008 & 2.063 & 0.9 \\
\hline 12 & 0.24 & 20 & 15 & 0.5 & 0.016 & 0.014 & 0.015 & \begin{tabular}{|l|l|}
0.015 \\
\end{tabular} & 0.016 & 0.19 & 4.3 \\
\hline 13 & 0.32 & 40 & 5 & 0.5 & 0.033 & 0.035 & 0.034 & 0.034 & 0.033 & 0.021 & 13.3 \\
\hline 14 & 0.24 & 40 & 5 & 0.5 & 0.047 & 0.047 & 0.041 & 0.045 & 0.041 & 0.923 & 120 \\
\hline 15 & 0.32 & 20 & 5 & 0.5 & 0.014 & 0.014 & 0.014 & 0.014 & 0.015 & 0.124 & 0.3 \\
\hline 16 & 0.24 & 20 & 5 & 0.5 & 0.027 & 0.027 & 0.032 & 0.029 & 0.023 & 3.364 & 87.03 \\
\hline \multicolumn{6}{|c|}{$\mathrm{Max} \mathrm{S}_{\mathrm{i}}^{2}=1.2 \cdot 10^{-5}$} & \multicolumn{4}{|c|}{$\Sigma\left(\mathrm{Y}_{\mathrm{i}}^{\mathrm{cp}}-\overline{\mathrm{Y}_{\mathrm{i}}}\right)^{2}=19.4 .10^{-5}$} & \multicolumn{2}{|c|}{$\mathrm{S}_{\mathrm{II}}^{2}=\sum \mathrm{S}_{\mathrm{i}}^{2}=2.66 .10^{-5}$} \\
\hline
\end{tabular}


The first-order regression equation and the values of the coefficients shown in formula (7), according to the calculated results obtained by Matlab program.

$$
\begin{aligned}
\mathrm{y}_{1}= & 0.02486-0.00406 \mathrm{x}_{1}+0.009315 \mathrm{x}_{2}-0.003227 \mathrm{x}_{3}-0.001823 \mathrm{x}_{4}-0.001223 \mathrm{x}_{1} \mathrm{x}_{2} \\
& +0.0007101 \mathrm{x}_{1} \mathrm{x}_{3}+0.000215 \mathrm{x}_{1} \mathrm{x}_{4}-0.001015 \mathrm{x}_{2} \mathrm{x}_{3}+0.0001396 \mathrm{x}_{2} \mathrm{x}_{4}+0.000223 \mathrm{x}_{3} \mathrm{x}_{4} \\
& -0.000727 \mathrm{x}_{1} \mathrm{x}_{2} \mathrm{x}_{3}-0.001448 \mathrm{x}_{1} \mathrm{x}_{3} \mathrm{x}_{4}-0.001173 \mathrm{x}_{2} \mathrm{x}_{3} \mathrm{x}_{4}+0.0003229 \mathrm{x}_{1} \mathrm{x}_{2} \mathrm{x}_{3} \mathrm{x}_{4}
\end{aligned}
$$

\subsubsection{Checking the significance of the coefficients of the regression equation}

According to $[8,9,13,14]$, checking the significance of the regression coefficients of the equation is performed by Student's criterion $\left(t_{\alpha}\left(f_{2}\right)\right)$. The coefficient $b_{j}$ is considered significant if:

$$
\mathrm{t}_{\mathrm{bi}} \geq \mathrm{t}_{\alpha}\left(\mathrm{f}_{2}\right)
$$

where: $t_{\alpha}\left(f_{2}\right)$ - the value Student's criterion, obtained from table 3.2 [15]. At a significant level of $\alpha=0.01$ and number of degrees of freedom $\mathrm{f}_{2}=\mathrm{N} \times(\mathrm{k}-1)=16 \times(3-1)=48$ obtained $\mathrm{t}_{0.001}$ $(48)=2.4066$.

The values of the Student's criterion $t_{b j}$ for the coefficients $b_{j}$ are determined by the formula (9):

$$
t_{b j}=\frac{\left|b_{j}\right|}{S_{b j}}
$$

where: $S_{b j}$ - dispersion estimates for the coefficients $b_{j}$ of the regression equation of the experiment, determined by formula (10):

$$
\mathrm{S}_{\mathrm{b} \delta}=\sqrt{\frac{\mathrm{S}_{\mathrm{Il}}^{2}}{\mathrm{~N}}}=\sqrt{\frac{2.66 .10^{-5}}{16}}=0.00129
$$

\begin{tabular}{|c|c|c|c|c|c|c|c|c|c|c|c|c|c|c|c|}
\hline $\mathrm{j}$ & 0 & 1 & 2 & 3 & 4 & 5 & 6 & 7 & 8 & 9 & 10 & 11 & 12 & 13 & 14 \\
\hline \multirow[b]{2}{*}{$b_{\mathrm{j}} \cdot 10^{-5}$} & $\mathrm{~b}_{0}$ & $b_{1}$ & $b_{2}$ & $b_{3}$ & $b_{4}$ & $\mathrm{~b}_{12}$ & $\mathrm{~b}_{13}$ & $b_{14}$ & $\mathrm{~b}_{23}$ & $\mathrm{~b}_{24}$ & $b_{34}$ & $\mathrm{~b}_{123}$ & $\mathrm{~b}_{134}$ & $\mathrm{~b}_{234}$ & $\mathrm{~b}_{1234}$ \\
\hline & 248.6 & $\begin{array}{c}- \\
40.6\end{array}$ & $\begin{array}{c}93.1 \\
5\end{array}$ & -322.7 & -182.3 & -122.3 & 71.01 & 21.5 & -101.5 & 13.96 & 22.3 & -72.7 & -144.8 & $\begin{array}{c}- \\
117.3\end{array}$ & 32.29 \\
\hline $\begin{array}{c}\left|b_{j}\right|_{-5} .10 \\
\end{array}$ & 248.6 & 40.6 & $\begin{array}{c}93.1 \\
5\end{array}$ & 322.7 & 182.3 & 122.3 & 71.01 & 21.5 & 101.5 & 13.96 & 22.3 & 72.7 & 144.8 & 117.3 & 32.29 \\
\hline \multirow{2}{*}{$t_{b j}$} & 19.2 & 3.1 & 7.2 & 2.50 & 1.41 & 0.94 & 0.55 & 0.16 & 0.78 & 0.10 & 0.17 & 0.56 & 1.12 & 0.9 & 0.25 \\
\hline & 9 & 5 & 3 & 4 & 4 & 9 & 1 & 6 & 7 & 8 & 3 & 4 & 4 & 1 & 1 \\
\hline
\end{tabular}

Table 10 are given the values of the Student's criterion for the coefficients of regression equation (6), according to the calculated results obtained by by the formula (9).

Table 10. The values of the Student's criterion of the coefficients of the regression equation (6)

After checking the significance of the coefficients of regression equation (6), insignificant coefficients were discarded, in the results of which the following equation was obtained:

$$
\mathrm{y}_{1}=0.02486-0.00406 \mathrm{x}_{1}+0.009315 \mathrm{x}_{2}-0.003227 \mathrm{x}_{3}
$$

\subsubsection{Checking the adequacy of the experimental model}

According to $[4,8,9,13,14]$, the adequacy of the regression equations is checked by means of the Fisher criterion. The calculated value of which is the following ratio (12):

$$
\mathrm{F}_{0}=\frac{\mathrm{S}_{\mathrm{d}}^{2}}{\mathrm{~S}_{\mathrm{ll}}^{2}}
$$


where: $S_{11^{-}}^{2}$ variance estimates the reproducibility of the experiment $S_{11}^{2}=\sum S_{i}^{2}=2.66 .10^{-5}$

$\mathrm{S}_{\mathrm{d}}^{2}$ - estimation of the dispersion of inadequacy, determined by the formula (8):

$$
S_{d}^{2}=\frac{\sum_{j=1}^{N}\left(Y_{j}-\bar{Y}_{j}\right)^{2}}{N-m}
$$

where: $m$ - the number of coefficients of the regression equation (6), which are significant, $\mathrm{m}=5$ and $\mathrm{N}=16$;

$Y_{j}$ - the observed value of the $\mathrm{i}$-th experiment (in Table 9);

$\bar{Y}_{j}$ - the obtained value of the experimental function in accordance with the $i$-th experiment (in Table 5);

$$
\mathrm{S}_{\mathrm{d}}^{2}=\frac{19 \cdot 4 \cdot 10^{-5}}{16-4}=1.62 \cdot 10^{-5} \rightarrow \mathrm{F}_{\text {pacc }}=\frac{\mathrm{S}_{\mathrm{d}}^{2}}{\mathrm{~S}_{\mathrm{ll}}^{2}}=\frac{1 \cdot 62 \cdot 10^{-5}}{2.66 \cdot 10^{-5}}=0.609
$$

$F_{\alpha},\left(f_{1}, f_{2}\right)$ - the value Fisher criterion, obtained from table 3.5 [15], with a significant level of $\alpha=0,01 ; \mathrm{f}_{1}$ - number of degrees of freedom for residual variance $\mathrm{f}_{1}=\mathrm{N}=16$ and $\mathrm{f}_{2}$ - number of degrees of freedom for estimating the variance of observations $\mathrm{f}_{2}=\mathrm{N}-\mathrm{m}=16-4=12$.

Consequently: $\mathrm{F}_{0.01}(16,12)=4.2509$.

As $\mathrm{F}_{0}=0.609<\mathrm{F}_{0.01}(16,12)=4.2509$, the experimental model described by mathematical regression equation (11) is adequate.

The regression equation (11) of experimental design showed that in the case of waterbinding ratio and the content of SF90 decrease, but the content of FA increase, the deformation of corrosion-resistant concrete prisms in $5 \% \mathrm{Na}_{2} \mathrm{SO}_{4}$ solution after 28 days of testing grow up. However, the effect of FA content is more pronounced than the waterbinding ratio and the content of SF90.

\section{Conclusion}

Using the American standard ACI 211.4R-08, the preliminary composition of the concrete mixture with standard slump cone of $16 \mathrm{~cm}$ was calculated. The corrosion-resistant concrete was obtained with $72.3 \mathrm{MPa}$ compressive strength and 6.15 $\mathrm{MPa}$ tensile strength at 28 day age of normal hardening.

1. The effect of fly ash, silica fume SF-90 and superplasticizer SilkRoad SR 5000F on the strength of corrosion-resistant concrete is obtained quickly, high early-strength concrete. In details, the compressive strength at the age of 1 and 3 days are respectively $29.6 \%$ and $61.13 \%$ in comparison to 28 days period.

2. The mathematical regression equation (11) of this experimental model is adequate, which was obtained by mathematical planning method for four influencing factors and the Matlab computer programs.

3. The deformation of corrosion-resistant concrete prisms were determined depending on the water-binding ratio, FA, SF90 and SR5000 contents in accordance with Russian standard GOST P 56687-2015. It was also noted that the effect of FA content is more pronounced than the water-binding ratio and SF90 content. In addition, the effect of SR5000 content on the deformation of concrete is negligible, so it was discarded. 


\section{References}

1. K. P. Mehta, Concrete in the marine environment (Taylor \& Francis Books, 2003)

2. N. X. Hung, T. V. Lam, B. I. Bulgakov, O. V. Aleksandrova, O. A. Larsen, H. H. Ky, Scien and Engin Jour, 6 (2018), DOI: 10.22227/1997-0935.2018.6.768-777.

3. T. V. Lam, B. I. Bulgakov, O. V. Aleksandrova, O. A. Larsen, N. X. Hung, N. D. V. Quang, Indus. and Civ. Constr. Jour., 8 (2017)

4. T. V. Lam, B. I. Bulgakov, B. Yuri, O. V. Aleksandrova, P. N. Anh, Mater. Scie. and Engin. 365 (2018), DOI: 10.1088/1757-899X/365/3/032007.

5. T. J. Paul, B. E. David, Synthesis guide to best practices for corrosion resistant concrete (University of Utah, 2008)

6. F. F. Chiara, E. S. Paul, A. S. Kenneth, Sulfate Resistance of Concrete: A New Approach (PCA, 2006)

7. Pilipenko Com. Mot. i Energ. Rol, 10 (2010)

8. T. V. Lam, B. I. Bulgakov, O. V. Aleksandrova, Scien. and Engin. Jour., 108 (2017), DOI: 10.22227/1997-0935.2017.9.999-1009

9. T. V. Lam, B. I. Bulgakov, O. V. Aleksandrova, O. A. Larsen, P. N. Anh and V. D. Tho, 33 (2018), https://doi.org/10.1051/e3sconf/20183302029

10. L. Z. Mei, W. Q. Su, L. X. Ai, App. Mech. and Mater., DOI: 10.4028/www.scientific.net/AMM.174-177.1265

11. B. Nabil, B. Abdelhafid, M. Merbouh, G. GlaouiBachir, Exter. Sulf. Atta. Portu., Lisbon, Portugal, 8 (2016),

12. T. V. Lam, B. I. Bulgakov, O. V. Aleksandrova, O. A. Larsen, P. N. Anh, 33 (2018), https://doi.org/10.1051/e3sconf/20183302030

13. N. M. Tuyen, Planning an experiment (Sci. and Techn., Hanoi, 2007)

14. P. T. Abomelik, Methodology of experiment planning (Ulyanovsk, 2006).

15. G. L. Astakhova, Mathematical Theory of Experiment Planning (Vladikavkaz, 2013) 